\title{
Synthesis and Characterization of Aluminium- Magnesium-Iron based Water Activated Ration Heater
}

\author{
Kyaw Ye Aung1, Dr.Maung Maung Myint ${ }^{2}$ \\ School of Environmental Engineering, Suzhou University of Science and Technology, Jiangsu Province, China ${ }^{1}$ \\ Department of Chemical Technology Science and Technology Research Centre, PyinOoLwin, Myanmar ${ }^{2}$
}

\begin{abstract}
In this paper, aluminium-magnesium-iron (Al-Mg-Fe) based water activated ration heater for ready foods was prepared by using a simple method. The effects of the difference molar ratio of precursors on the thermal properties of water activated ration heater had been investigated. According to FLIR study, (Al-Mg-Fe) based water activated ration heater synthesized by using ( $\mathrm{Al}-\mathrm{Mg}-\mathrm{Fe}$ ) mixture and $\mathrm{NaCl}$ reaches the peak temperature $91.5^{\circ} \mathrm{C}$ and the highest average temperature of $75.75{ }^{\circ} \mathrm{C}$ within 12 minutes. According to the XRD result, aluminium-magnesium-iron based water activated ration heater synthesized by using 1:0.75 mass ratio of ( $\mathrm{Al}-\mathrm{Mg}-\mathrm{Fe}$ ) mixture and $\mathrm{NaCl}$ has the complete reaction. These mass ratio was also get the best results in the performance of heating test continue again.
\end{abstract}

Keywords: Water activated ration heater, aluminium-magnesium-iron powder, FLIR study, XRD, $\mathrm{NaCl}$

\section{INTRODUCTION}

Food items, such as rations for backpackers, explorers and armed forces, are known to provide sealed packets of precooked food.[1] The food is easily hermetically sealed in a vacuum; the food can be heated on demand and, as such, it would not be necessary to prepare the food.[2] These food products and equipment are referred to collectively as MealsReady-to-Eat ("MRE"). [3]

The products may be used, in addition to all the above uses, as emergency rations for shelters and for heating non-food products.[4] Although ready-to-eat meals are commonly used in the military as a means of supplying soldiers with meals while in the field, others, such as campers, boaters, and disaster response teams, are also making their way into use. [5]. Rations should optimally be maintained during storage in a cold, dry spot. The rations would hit the end of their shelf life if they were kept $80^{\circ}$ for 3 consecutive years. The USA inspects them regularly. The veterinary food workers of the Army can extend its shelf-life beyond the test date. After five years, rations are rejected. [6].

Typically, meals prepared to eat food sachets are provided on a personal basis, as heat transfer problems may arise in larger packages. Compared to eating such food cold, which can be done incidentally, food is heated to an appropriate temperature, about $70{ }^{\circ} \mathrm{C}$ or more, to make it a more pleasurable experience. In addition, when the outer wall of the exothermic material storage section is not properly thermally sealed, there is a danger of burning. Such foods are therefore usually prepared utilizing exothermic chemical reactions by heating with water-activated ration heaters. [7]. An exothermic reaction of calcium carbonate, sodium carbonate, calcium oxide as well as aluminum powder mixture can be used in one known type of water activated ration heater. In another type of water-activated ration heater, easily oxidized metals, such as magnesium, which is activated by the addition of water and is contained within a container. Iron plays a catalytic role in the mixture of heaters; salt can be added to facilitate reaction. In either case, a quantity of water is added to activate the reaction.in the heater mix; salt can be added to facilitate the reaction.

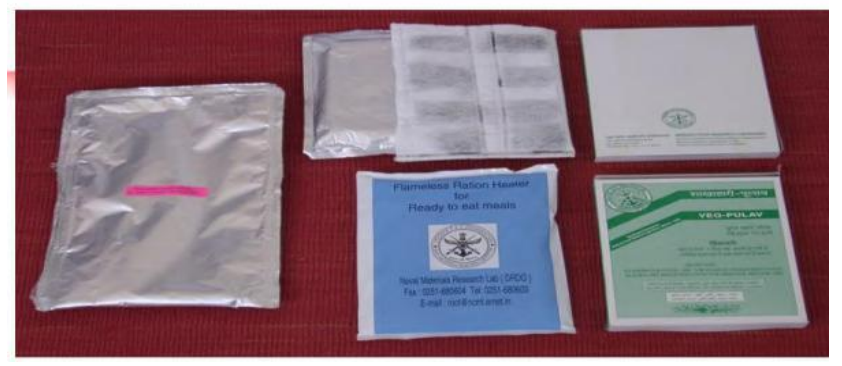

Fig.1 Flameless ration heater for MRE 
In this paper, a simple method was used to prepare a water-activated ration heater based on aluminium-magnesium-iron (Al-Mg-Fe). The effects of the molar difference ratio of precursors on the thermal properties of the water-activated ration heater were evaluated.

\section{MATERIALS}

Aluminium powder (Al), Magnesium powder $(\mathrm{Mg})$, Iron powder $(\mathrm{Fe})$ and sodium chloride $(\mathrm{NaCl})$ were purchased from Myanma Supply Company Limited.

\section{EXPERIMENTAL}

\section{A. Preparation of Water Activated Ration Heater}

Firstly, aluminium powder, magnesium powder and iron powder (0.275:0.72:0.005 mass ratio) were milled with the centrifugal milling machine ( 0.08 micrometer diameter sieve) at $3500 \mathrm{rpm}$ for 2 minutes. The difference mass ratio of $\quad(1: 0.25,1: 0.5,1: 0.75$ and 1:1) aluminium powder/ magnesium powder/ iron powder mixture and sodium chloride were mixed in a Heavy Duty Stirrer for 2 hours.

\section{RESULT AND DISCUSSION}

\section{A. FLIR Study of Water Activated Ration Heater}

In a water-activated ration heater, a mixture of aluminium/magnesium/iron is brought into contact with water or an ion-conducting solution, thereby corroding the mixture to produce heat. Due to the formation of an oxide/hydroxide layer on the surface of magnesium and aluminium, the reaction between magnesium/aluminium and water is relatively slow, but the addition of iron to the magnesium/aluminium mixture has been found to speed up

Anode $=$ Magnesium

Cathode $=$ Aluminum or Iron

Electrolyte $=\mathrm{NaCl}$ solution in water

$$
\mathrm{Mg}+2 \mathrm{H}_{2} \mathrm{O}=\mathrm{Mg}(\mathrm{OH})_{2}+\mathrm{H}_{2}
$$

Anode $=$ Aluminum

Cathode $=$ Iron

Electrolyte $=\mathrm{NaCl}$ solution in water

$2 \mathrm{Al}+6 \mathrm{H}_{2} \mathrm{O}=\mathrm{Al}(\mathrm{OH})_{3}+3 \mathrm{H}_{2}$

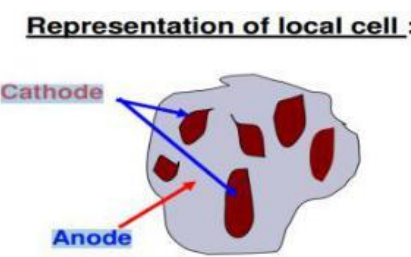

Fig.2: Possible formation of electrochemical cell of Al-Mg-Fe water activated ration heater with cathode (Fe) and anode (Al-Mg)

The temperature changes of the aluminium-magnesium-iron based water activated ration heater, synthesis by using difference mass ratio of aluminium-magnesium- iron mixture and sodium chloride were recorded by using FLIR (Fig. 3). First, $15 \mathrm{~g}$ of the well-mixed water activated ration heater powder synthesized by using 1:0.25 mass ratios of Al-Mg$\mathrm{Fe}$ mixture and $\mathrm{NaCl}$ was placed in a beaker, and then $12 \mathrm{ml}$ of water was added to the beaker. The temperature of the reaction mixture was monitored and the time from addition of the $12 \mathrm{ml}$ of water was recorded. The results are shown in Fig. 4. The Water Activated Ration Heater was tested and evaluated extensively for its ability to meet military users' needs. The Water Activated Ration Heater must be heated the MRE entree in approximately 12 minutes. For Al-Mg.Fe water activated ration heater, the amount of water needed to activate the heater, was calculated by fixing $0.25 \mathrm{~N}$ 


\section{International Advanced Research Journal in Science, Engineering and Technology}

Vol. 8, Issue 2, February 2021

\section{DOI: $10.17148 / I A R J S E T .2021 .8223$}

concentration of electrolyte solution. So, the amount of water needed to activate heaters synthesized by using 1:0.5, 1:0.75 and 1:1 were $24 \mathrm{ml}, 36 \mathrm{ml}$ and $48 \mathrm{ml}$ respectively. The results are shown in Fig. 5, 6 and 7.

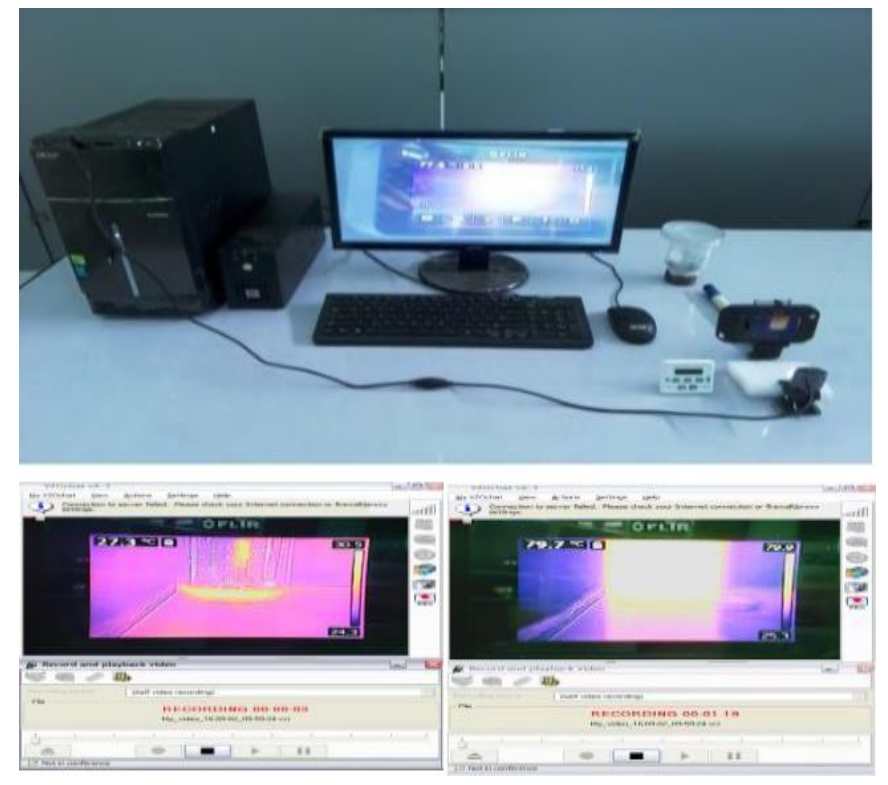

Fig.3 FLIR system for recording temperature changes of water activated ration heater

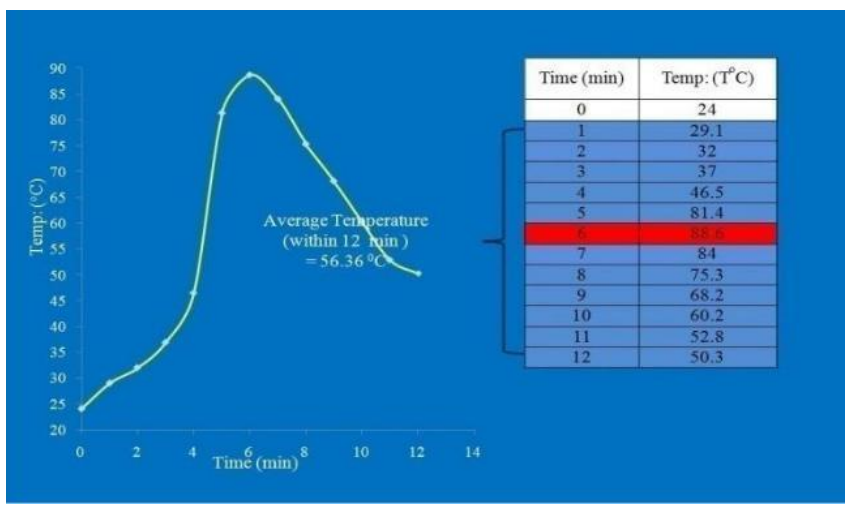

Fig.4 Temperature changes graph of Al-Mg-Fe based water activated ration heater synthesized by using 1:0.25 mass ratio of Al-Mg-Fe mixture and sodium chloride, react with $12 \mathrm{ml}$ water

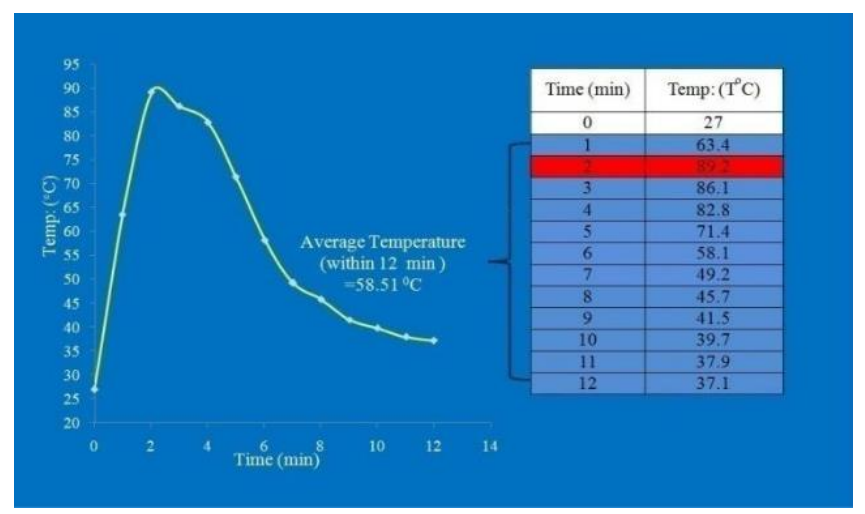

Fig .5 Temperature changes graph of Al-Mg-Fe based water activated ration heater synthesized by using 1:0.5 mass ratio of $\mathrm{Al}-\mathrm{Mg}$-Fe mixture and sodium chloride, react with $24 \mathrm{ml}$ water 


\section{International Advanced Research Journal in Science, Engineering and Technology}

Vol. 8, Issue 2, February 2021

DOI: $10.17148 /$ IARJSET.2021.8223

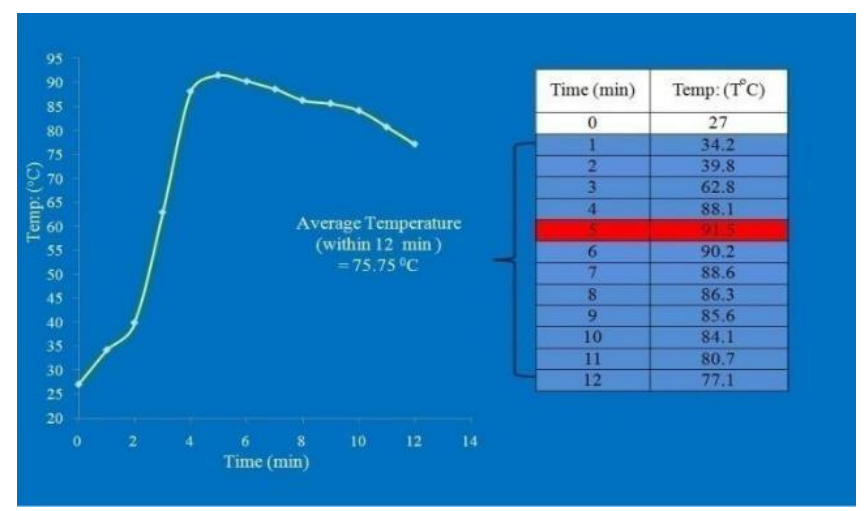

Fig .6 Temperature changes graph of Al-Mg-Fe based water activated ration heater synthesized by using 1:0.75 mass ratio of $\mathrm{Al}-\mathrm{Mg}-\mathrm{Fe}$ mixture and sodium chloride, react with $36 \mathrm{ml}$ water

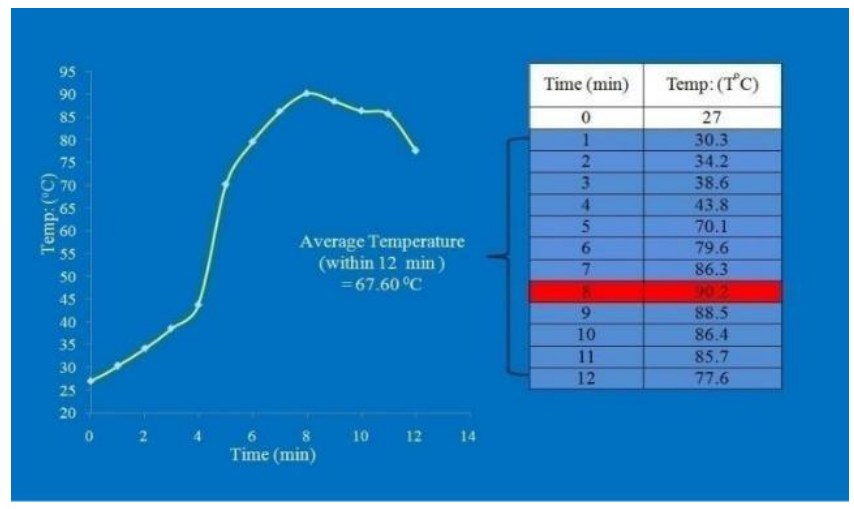

Fig .7 Temperature changes graph of Al-Mg-Fe based water activated ration heater synthesized by using 1:1 mass ratio of Al-Mg-Fe mixture and sodium chloride, react with $48 \mathrm{ml}$ water

According to results, aluminium-magnesium-iron based water activated ration heater synthesized by using 1:0.75 mass ratio of aluminium-magnesium-iron mixture and sodium chloride reach the peak temperature $91.5^{\circ} \mathrm{C}$ and the highest average temperature of $75.75^{\circ} \mathrm{C}$ within 12 minutes.

\section{B. XRD Study}

X-ray powder diffraction patterns of Al-Mg-Fe based water activated ration heaters are illustrated in Fig. 8,9,10 and 11 . Patterns were obtained from Al-Mg-Fe based water activated ration heater prepared by using difference mass ratios of aluminium-magnesium-iron mixture and $\mathrm{NaCl}$. According to the results, aluminium, magnesium and $\mathrm{NaCl}$ were observed in the samples, which were synthesized by using 1:0.25, 1:0.5 mass ratio of Al-Mg-Fe mixture and $\mathrm{NaCl}$. But, for the samples synthesized by using 1:0.75 and 1:1 mass ratio of $\mathrm{Al}-\mathrm{Mg}-\mathrm{Fe}$ mixture and $\mathrm{NaCl}$, only $\mathrm{NaCl}$ had been observed. According to the results, complete reaction was occurred when using 1:0.75 and 1:1 mass ratios of $\mathrm{Al}-\mathrm{Mg}-\mathrm{Fe}$ mixture and $\mathrm{NaCl}$. According to lecturer, the products must be hydroxide or oxide form of aluminium and magnesium, but in all XRD results, any of those products had not been observed. Assume that, both products were formed as amophorous form. From FLIR study, Al-Mg-Fe based water activated ration heater synthesis by using 1:1 mass ratio of Al-Mg-Fe mixture and $\mathrm{NaCl}$ has highest average temperature within 12 minutes, it can be assumed that, at that mass ratio, the electrochemical reaction of Al-Mg-Fe mixture is complete and release highest amount of heat energy. If the amount of $\mathrm{NaCl}$ was increased (concentration of electrolyte was increased) from 1:0.75 to 1:1, the average temperature decreased again, because of the excess amount of $\mathrm{NaCl}$. So, Al-Mg-Fe based water activated ration heater synthesized by using 1:0.75 mass ratios of $\mathrm{Al}-\mathrm{Mg}-\mathrm{Fe}$ mixture and $\mathrm{NaCl}$ has been chosen as the best $\mathrm{Al}-\mathrm{Mg}$-Fe based water activated ration heater. 
International Advanced Research Journal in Science, Engineering and Technology

Vol. 8, Issue 2, February 2021

DOI: $10.17148 / I A R J S E T .2021 .8223$

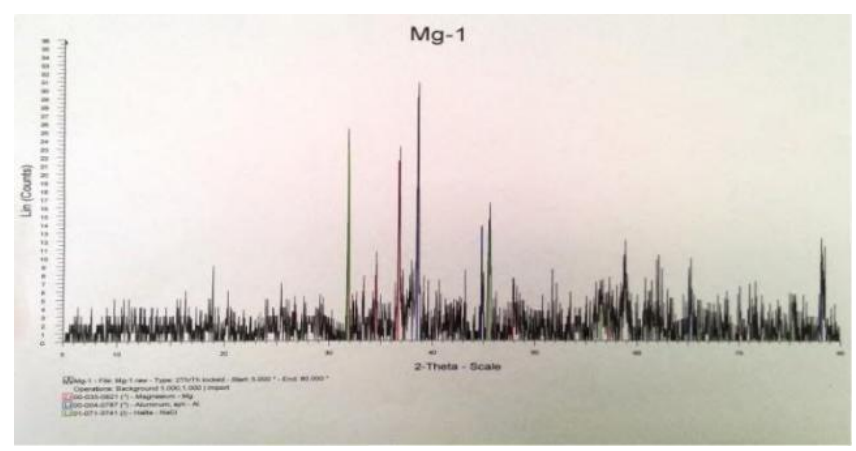

Fig.8 XRD Patterns of synthesized Al-Mg-Fe based water activated ration heater synthesized by using 1:0.25 mass ratio of Al-Mg-Fe mixture and sodium chloride, react with $12 \mathrm{ml}$ water

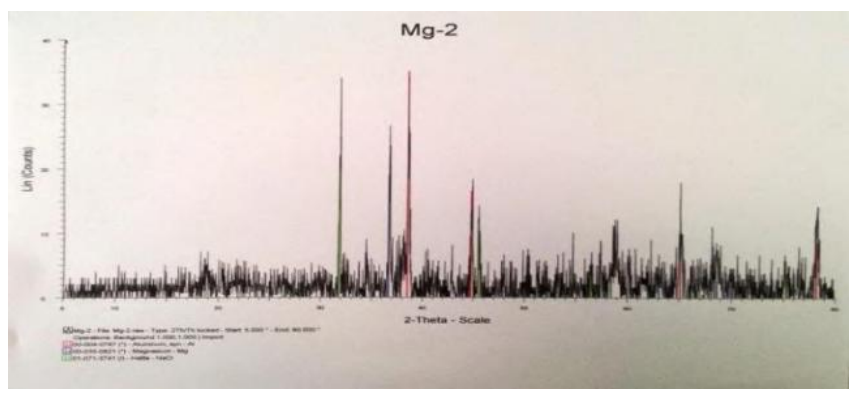

Fig.9 XRD Patterns of synthesized Al-Mg-Fe based water activated ration heater synthesized by using 1:0.5 mass ratio of Al-Mg-Fe mixture and sodium chloride, react with $24 \mathrm{ml}$ water

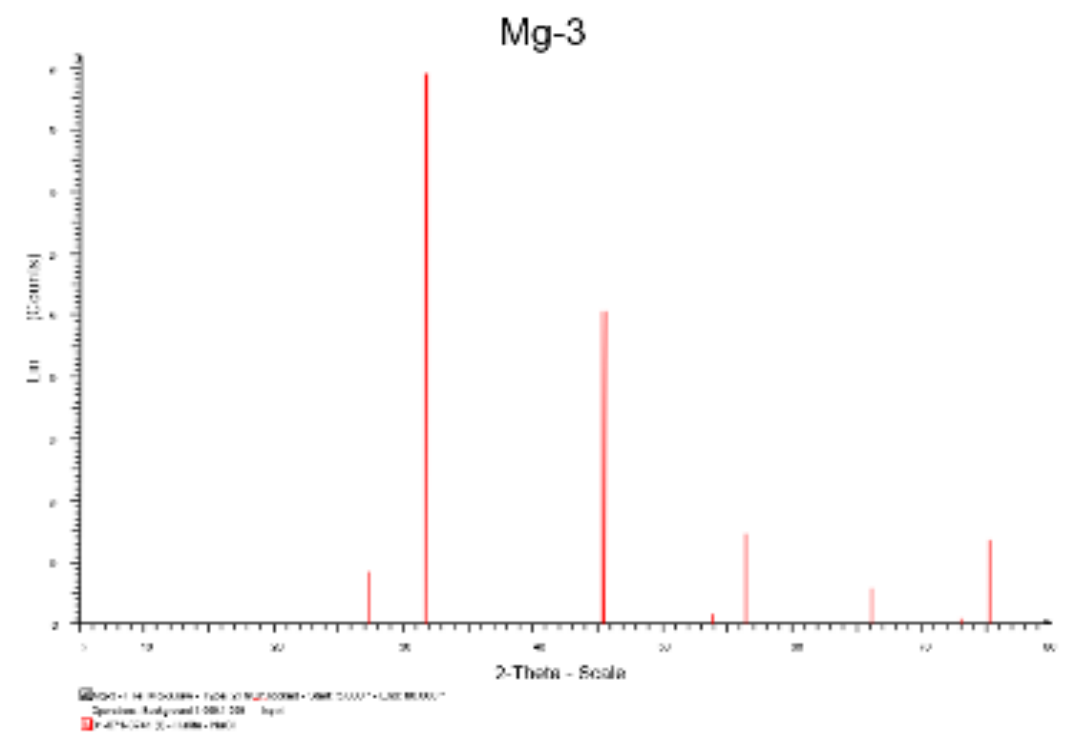

Fig.10 XRD Patterns of synthesized Al-Mg-Fe based water activated ration heater synthesized by using 1:0.75 mass ratio of Al-Mg-Fe mixture and sodium chloride, react with $36 \mathrm{ml}$ water 


\section{International Advanced Research Journal in Science, Engineering and Technology}

Vol. 8, Issue 2, February 2021

DOI: $10.17148 /$ IARJSET.2021.8223

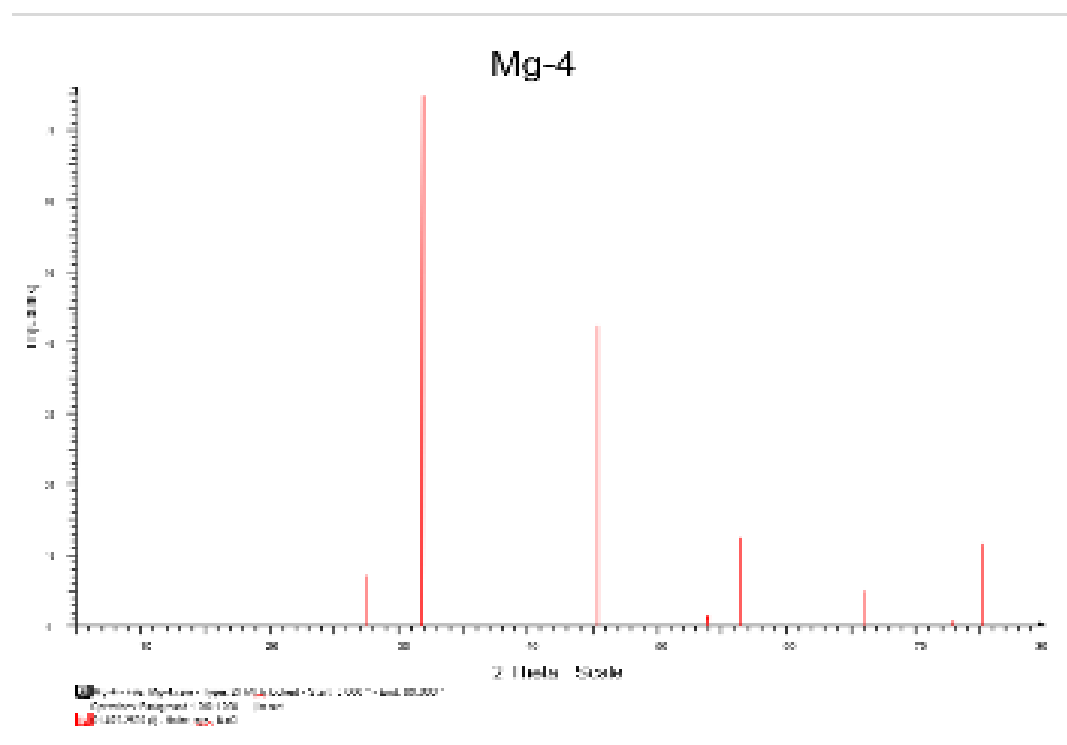

Fig.11 XRD Patterns of synthesized Al-Mg-Fe based water activated ration heater synthesized by using 1:1 mass ratio of Al-Mg-Fe mixture and sodium chloride, react with $48 \mathrm{ml}$ water

\section{Heating Performance Test}

In order to meet the technical needs, any heater intended for use with the MRE must be capable of heating one 8 oz. $(230 \mathrm{~g})$ intake pouch from $40^{\circ} \mathrm{F}\left(4^{\circ} \mathrm{C}\right)$ to $140^{\circ} \mathrm{F}\left(60^{\circ} \mathrm{C}\right)$ within 12 minutes. A number of assumptions must be made to achieve this heating: the heat capacity of food is equivalent to that of water $(4.18 \mathrm{~kJ} / \mathrm{kg} \cdot \mathrm{K})$ and the entrance pouch is assumed to be a two-dimensional flat wall. In practice, the heat capacity (thermal conductivity) of food is slightly lower than that of water. In order to test the heat generation, $20 \mathrm{~g}$ of the well-mixed Al-Mg-Fe powder was placed in a 3-cell container made of a woven oxidation-resistant material (Fig.12). For the first time, the two sachets containing $20 \mathrm{~g}$ of well-mixed Al-Mg-Fe powder were placed in a plastic bag in which a sealed plastic pouch containing $230 \mathrm{~g}$ of water was placed (Fig.14) to represent a meal package as known from ready-to-eat meals. Then a quantity of $96 \mathrm{ml}$ of water was added to the plastic bag containing both FRH packages and a water plastic bag. The temperature of $230 \mathrm{~g}$ of water was monitored using FLIR(Fig.15).

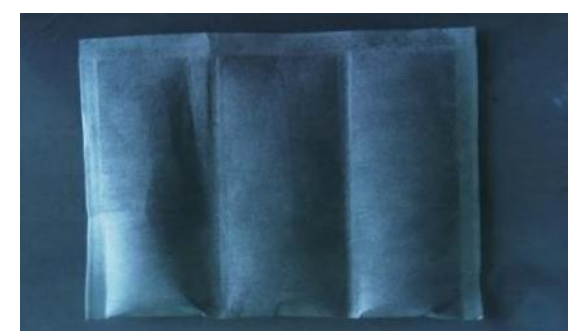

Fig.12 Water activated ration heater package containing $20 \mathrm{~g}$ of Al-Mg-Fe based water activated ration heater

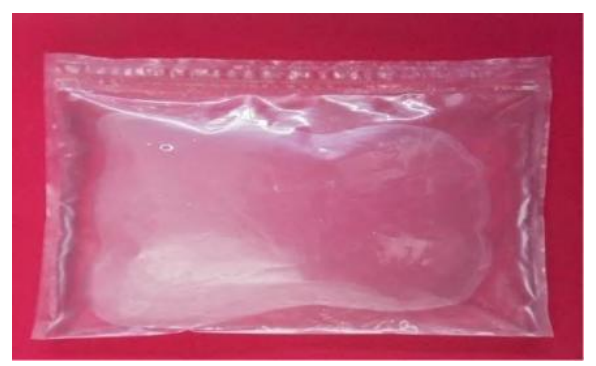

Fig.13 Sealed plastic pouch containing $230 \mathrm{~g}$ of water 


\section{International Advanced Research Journal in Science, Engineering and Technology}

Vol. 8, Issue 2, February 2021

DOI: $10.17148 / I A R J S E T .2021 .8223$

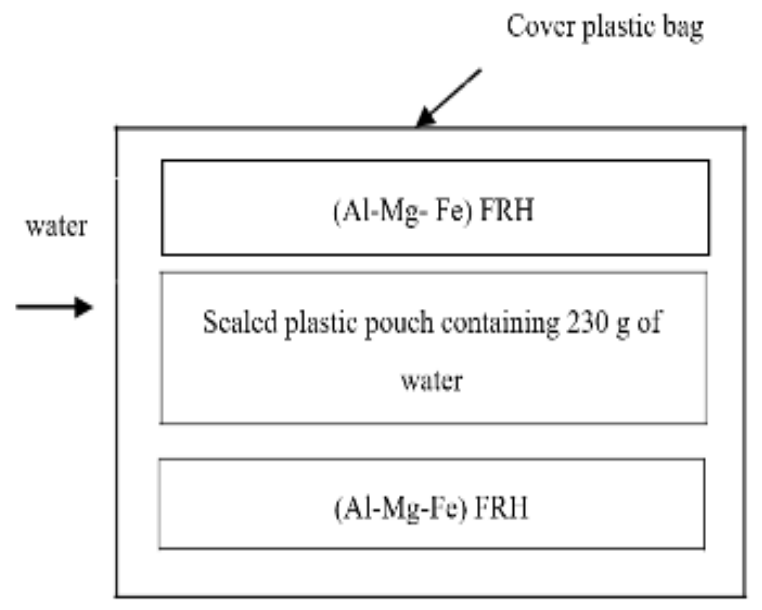

Fig.14 Schematics diagram of heating performance test

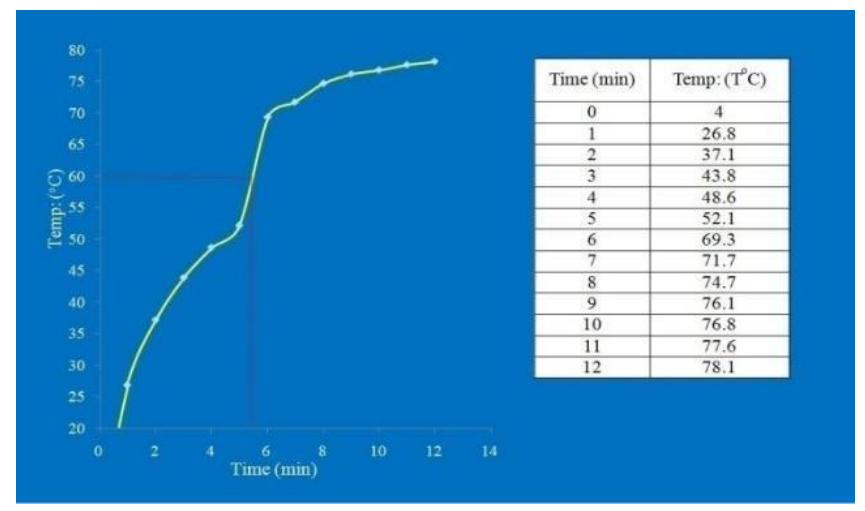

Fig.15 Temperature changes graph of $230 \mathrm{~g}$ water $\left(4^{\circ} \mathrm{C}\right)$ heated by using $40 \mathrm{~g}$ Al-Mg-Fe based water activated ration heater synthesized with 1:0.75 mass ratio of of Al-Mg-Fe mixture and sodium chloride

\section{CONCLUSION}

Al-Mg Fe based water activated ration heater had been synthesized by using simple method. According to the results, water activated ration heater synthesized by using 1:0.75 mass ratio of $\mathrm{Al}-\mathrm{Mg}-\mathrm{Fe}$ mixture and $\mathrm{NaCl}$ has highest average temperature of $75.75^{\circ} \mathrm{C}$ within 12 minutes. The heater meets the Army specification of increasing the temperature of an eight-ounce water pouch from $40^{\circ} \mathrm{F}$ to $140^{\circ} \mathrm{F}\left(+100^{\circ} \mathrm{F}\right)$ in less than 12 minutes. It is possible to use the Al-Mg-Fe based water activated ration heater in larger prepared food arrangements, suitable for providing heat whereby to cook food and for meals other than for one person. It is noted, however, that many foods for outdoor use are already cooked and merely require heating - that is to say the temperature achieved in heating is not critical, for example when re-heating food that has already been cooked.

\section{REFERENCES}

[1] Marc Lamensdrof "Flameless heater and method of making same",USP 5611329 A(Mar 18, 1997).

[2] Lee JS, Kim ST, Cao RG, Choi NS, Liu ML, Lee KT, et al. Metale air batteries with high energy density: Lieair versus Zneair. Adv Energy Mater 2011; 1:34e50. S.M Somani (Ed.), Chemical Warfare Agents, Academic, San Diego, 1992.

[3] Hasvold Q, Henriksen H, Melvaer E, Citi G, Johansen BQ, Kjqnigsen T, et al. Sea-water battery for subsea control systems. J Power Sources 1997; 65:253e61.

[4] Sergev, Sergius S.; Black, Stanley A.; Jenkins, James F., "Supercorroding Galvanic Cell Alloys for Generation of Heat and Gas", USP 4,264,362 (April 28, 1981).

[5] Kuhn, William E.; Hu, Kwoh H.; Black, Stanley A. "Flexible Electrochemical Heater", USP 4,522,190 (June 11, 1985).

[6] "Operational Rations of the Department of Defense". Aug 2012. Retrieved 6 October 2019.

[7] Tinker, L.; Kainthla, R.; Sesock, C.; Patel, B.; "Oxygen Activated Heater and Method of Manufacturing Same", PCT Publication WO 2008/022044 (February 21, 2008). 